\section{Når livet blir for stort}

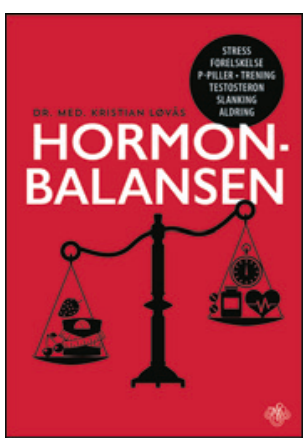

Kristian Løvås

Hormonbalansen

255 s, ill. Oslo: J.M. Stenersens Forlag, 2014

NOK 349

ISBN 978-82-7201-570-0
«Vi vil leve lenge vi, men gamle vil vi aldri bli», synger Halfdan Sivertsen. Stadig flere pasienter føler at de ikke strekker til i sine travle liv. Likevekten har trange kår, og både fastleger og endokrinologer ser mange pasienter med bestillingen: «Det må jo være noe galt med hormonene sånn som jeg har det nå!»

Alternative fora på internett har fylt et formidlingstomrom, ofte med dårlig dokumenterte påstander. I Hormonbalansen skiller endokrinolog Kristian Løvaas hva vi vet, fra hva vi ikke vet, på en faglig velfundert og pedagogisk måte som er forståelig for folk flest.

De viktigste hormonsykdommene med mangeltilstander eller overskudd settes i både normalfysiologisk og historisk perspektiv, illustrert ved hjelp av pasientene Hanne, i 40-årene med hypotyreose og klimakterielle plager, og Jan, 60 år, overvektig og med type 2-diabetes. Deretter følger kapitler om hvordan livsstil og miljø påvirker hormonbalansen, betydningen av epigenetikk og autoimmunitet som renovasjonsmekanisme. Forfatteren tar videre opp spørsmål rundt fertilitetsproblemer og lengdevekst, illustrert ved fotballspilleren Messi. Doping og anti-aldringshormonsubstitusjon avrunder boken.

Målet er økt salutogenese eller «sense of coherence». Utgangspunktet er at «skjebnen er et bra sammensurium av fornuft og flaks», og det gjennomgående budskapet er at «det gjelder å endre på det som kan og bør endres, dernest akseptere oss selv som vi er og hva vi ikke kan endre». Redskapene som Hanne, Jan og andre kan gjøre bruk av, er «moderat fysisk aktivitet, mindre stress, balansert kost og færre kalorier». Løvaas synes det er bedre å «gjøre litt av alt det som er billig og bra enn mye som er dyrt og tvilsomt». Forfatteren er klar på at alt står for hans regning - men til sjuende og sist er vi nok mange som deler Løvaas' standpunkter og råd.

Det eneste minuset er at rådene blir lite konkrete, for eksempel: «Mosjon er den beste og billigste medisin som virker på alt og er uten bivirkninger» og «spis mat, litt mindre, mest planter». Men faktisk er det ofte så lett og så vanskelig på samme tid. Mer konkrete råd vil pasientene kanskje kunne diskutere med fastlegen, men antakelig blir det lettere å hjelpe både Hanne, Jan og andre videre på rett vei når grunnlaget er lagt med denne boken.

Boken er velskrevet og nøkternt populærvitenskapelig. Jeg anbefaler den for både indremedisinere og fastleger med pasienter hvor livet er blitt for stort. Jeg håper flere, meg selv inkludert, vil anbefale den som lektyre til disse pasientene.

Løp og kjøp - og ta en ekstra omvei på vei hjem hvis du orker!

Mikkel Peter Høiberg

Lege i spesialisering, Medisinsk avdeling

Sørlandet sykehus, Kristiansand

\section{Vitnesbyrd fra en systematisk fryktkultur}

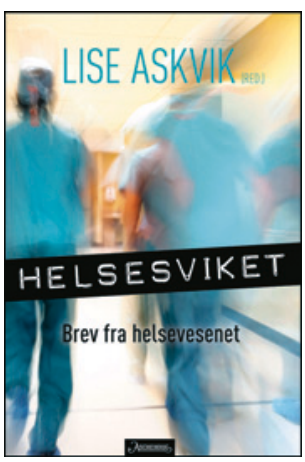

Lise Askvik, red.

Helsesviket

Brev fra helsevesenet. 221 s. Oslo: Aschehoug, 2015. Pris NOK 299

ISBN 978-82-03-29530-0

Journalist og programleder Lise Askviks profilerte helsepolitiske engasjement springer ut av personlige pasienterfaringer. Disse erfaringene vekket hennes journalistiske instinkter. Da hun begynte å spørre og grave, ble hun forundret over frykten og tilbakeholdenheten hun møtte. Etter hvert forsto hun hvilken omfattende risiko det medfører for medarbeidere i helsevesenet å stå frem med kritikk av systemet. Systemet reduserer historiene fra virkeligheten til sekundære måltall som legges til grunn for ledelsens beslutninger. Da blir det lett for ledelsen å ignorere variasjonene og kompleksiteten i de situasjonene helsearbeiderne skal mestre.

Som journalist vet Askvik hvordan historier fra virkeligheten kan fortelle oss mer om hvordan systemene fungerer enn tolkninger av aggregerte måltall. Derfor har hun i Helsesviket valgt å presentere en serie vitnesbyrd fra forskjellige fagfolk som reflekterer over sine erfaringer på sine respektive lokale arenaer i helsevesenet.

Lise Askvik ba bidragsyterne formulere sine vitnesbyrd som personlige brev. Brevene er oppriktige og dyptfølte. Det er stor spennvidde $\mathrm{i}$ erfaringene $\mathrm{og}$ refleksjonene som meddeles. Vi får betroelser fra både nyutdannede og profilerte nestorer. I alle vitnesbyrdene vibrerer den samme indignerte harmen. De faglige holdningene og verdiene som motiverer en helsearbeider, korresponderer gjerne med personlig livssyn og ledemotiv. Derfor kan konflikten mellom faglige hensyn og hensynet til systemet bli en dyp sjelelig utfordring for folk i helsevesenet. Noen av brevskriverne forteller om vedvarende skyldfølelse, og hvordan det virker demoraliserende og utmattende ikke å få anledning til å leve opp til de idealene og standardene som motiverer dem. Andre uttrykker sorg og fortvilelse over hvordan faglige standarder og fremragende fagmiljøer forvitrer.

Harmen retter seg mot systemet, mot den industrielle forretningslogikken i systemet, og mot virkningene av denne fremmedgjørende tenkningen. Dette er massivt - og tungt å bære alene. Derfor er disse samvittighetsfulle vitnesbyrdene viktige og verdifulle.

I sine egne tekster kritiserer Askvik informasjonsgrunnlaget og de politiske prosessene som ledet frem til dagens system. Helsesviket etterlater inntrykket av et system som er blitt seg selv nok. Faglig og etisk begrunnet kritikk tolkes som illojalitet og møtes med mistenkeliggjøring og trusler om utestenging. Begrepet «fryktkultur» er i ferd med å feste seg. Lise Askviks bok henvender seg til folkestyret og allmennheten som eier, medarbeidere, pasienter og pårørende, og krever at vi tar inn over oss hvor dyp og omfattende tillitskrisen i helsevesenet er.

\section{Johan Nygaard}

Frittstående skribent Billingstad

Oppgitte interessekonflikter: Anmelder har selv som skribent bidratt i de helsepolitiske debattene i dagspresse og tidsskrifter, og kjenner Askvik og noen av bidragsyterne gjennom deltakelse på det uavhengige, helsepolitiske forumet Aja. 